\title{
Erratum to: Geomicrobiology of Iron Layers in the Sediment of Lake Superior
}

\author{
M. Dittrich ${ }^{1}$ - L. Moreau ${ }^{1}$ J. Gordon ${ }^{1}$ • \\ S. Quazi ${ }^{1}$ - C. Palermo' ${ }^{1}$ R. Fulthorpe ${ }^{1}$. \\ S. Katsev ${ }^{2}$ J. Bollmann ${ }^{3} \cdot$ A. Chesnyuk ${ }^{1}$
}

Received: 31 March 2015/Accepted: 31 March 2015/Published online: 12 April 2015

(C) Springer Science+Business Media Dordrecht 2015

\section{Erratum to: Aquat Geochem DOI 10.1007/s10498-015-9258-y}

After the article has been published online, the authors noticed that the Table 1a in the Supplementary material is not the table from the accepted manuscript.

Table 1a should be corrected to the following:

Two rows for $\mathbf{2 0 . 5} \%$ and $3.5 \%$ Reads should be exchanged as shown in the table below. For the rows

Reads $4.7 \%$ : FJ497180 Uncultured bacterium clone Pm_planulaeLM_G11; Coverage, Max Identity: 99, 86; Habitat: Associate of coral should be exchanged with $D Q 404779$ Uncultured bacterium clone 661230; Coverage, Max Identity: 98, 91; Habitat: Contaminated sediment. The first set of Coverage, Max Identity values $(98,91)$ should be removed, and the remaining values 86,94 and 96,89 should be moved up so that they correspond with the correct bacterial classifications.

Reads 3.7 \%: JX825743.1 Uncultured bacterium clone GD2::G9RA0RH03GJRTH; Coverage, Max Identity: 94, 99; Habitat: Lava Caves should be exchanged with AM909970 Uncultured bacterium clone LM63; Coverage, Maximal Identity: 100, 96; Habitat: Rhizosphere soil from rice field, China.

The online version of the original article can be found under doi:10.1007/s10498-015-9258-y.

M. Dittrich

mdittrich@utsc.utoronto.ca

1 Department of Physical and Environmental Sciences, University of Toronto Scarborough, Toronto, ON, Canada

2 Large Lakes Observatory and Department of Physics, University of Minnesota Duluth, Duluth, MN, USA

3 Department of Earth Sciences, University of Toronto, Toronto, ON, Canada 
Reads $2.1 \%$ : AF293000 Uncultured Green Bay ferromanganous micronodule bacterium MNG3; Coverage, Max Identity: 100, 89; Habitat: freshwater ferromanganous micronodules and sediments should be exchanged with JF830230 Bacterium enrichment culture clone B180; Coverage, Maximal Identity: 100, 96; Habitat: Grass carp intestine enrichment on BHI.

\begin{tabular}{|c|c|c|c|}
\hline \% Reads & $\begin{array}{l}\text { Closest Match and RDP II } \\
\text { Classification }\end{array}$ & Coverage, Max Identity & Habitat \\
\hline \multirow[t]{4}{*}{20.5} & $\begin{array}{l}\text { FJ810544 Uncultured bacterium } \\
\text { clone JMYB12-12 }\end{array}$ & 100,88 & $\begin{array}{l}\text { Coal tar waste- } \\
\text { contaminated } \\
\text { groundwater }\end{array}$ \\
\hline & $\begin{array}{l}\text { EU546359 Uncultured bacterium } \\
\text { clone LWS-T4601 }\end{array}$ & 95,88 & $\begin{array}{l}\text { Lake Washington } \\
\text { sediments }\end{array}$ \\
\hline & $\begin{array}{l}\text { HM447116 Uncultured bacterium } \\
\text { clone OM3-105 }\end{array}$ & 95,88 & $\begin{array}{l}\text { Pristine groundwater } \\
\text { sample, Hungary }\end{array}$ \\
\hline & Unclassified Bacteria & & \\
\hline \multirow[t]{4}{*}{3.5} & $\begin{array}{l}\text { FR754468 Uncultured bacterium } \\
\text { clone }\end{array}$ & 100,84 & $\begin{array}{l}\text { Biofilm wall of karst } \\
\text { cave, Hungary }\end{array}$ \\
\hline & $\begin{array}{l}\text { AM991193 Uncultured bacterium } \\
\text { M6A-202 }\end{array}$ & 90,95 & $\begin{array}{l}\text { Karst groundwater, } \\
\text { Switzerland }\end{array}$ \\
\hline & $\begin{array}{l}\text { DQ828624 Uncultured bacterium } \\
\text { clone DOK_CONFYM_clone364 }\end{array}$ & 100,91 & Agricultural soil \\
\hline & Unclassified Bacteria & & \\
\hline
\end{tabular}

